\title{
ON-FARM STUDY ON INTERCROPPING OF HYBRID MAIZE WITH DIFFERENT SHORT DURATION VEGETABLES IN THE CHARLAND OF TANGAIL
}

\author{
M. A. Rahaman ${ }^{1}$, M. M. Rahman ${ }^{1}$, S. Roy ${ }^{1}$, M. Ahmed ${ }^{2}$ and M. S. Bhuyan ${ }^{3}$ \\ ${ }^{1}$ OFRD, BARI, Tangail \\ ${ }^{2}$ Vertebrate Pest Division, BARI, Gazipur and \\ ${ }^{3}$ Agronomy Division, BARI, Gazipur
}

Keywords: Intercropping, Maize (Zia mays), Vegetables, Yield, Cost-benefit

\begin{abstract}
An experiment was conducted in charland at the Multi Location Testing (MLT) site Bhuapur, Tangail during 2012-13 and 2013-14 under AEZ-8 to find out the suitable intercropping system of hybrid maize with different short duration vegetables with economic return. The experiment was laid out in RCB design with six dispersed (six farmers' field) replications. The hybrid maize (ver. BARI Hybrid maize-7), potato (Diamant), spinach (local), red amaranth (BARI Lalsak-1), Radish (BARI Mula-1) were used as the planting materials. Five treatment combinations viz. $T_{1}=$ Sole Maize, $T_{2}=100 \%$ Maize (maize paired row) + Potato (var. Diamant), $T_{3}=100 \%$ Maize (maize paired row) + Spinach (var. local), $T_{4}=100 \%$ Maize (maize paired row) + Red amaranth (var. BARI Lalshak-1) and $T_{5}=100 \%$ Maize (Maize paired row) + Radish (var. BARI Mula-1) were studied. Maize grain yield in intercropped combination varied from 5.59-7.62 $\mathrm{t} \mathrm{ha}^{-1}$. But the highest grain yield $\left(8.17 \mathrm{tha}^{-1}\right)$ was obtained from sole maize. Maize equivalent yields in the intercrops situation ranged from 11.39-19.68 $\mathrm{t} \mathrm{ha}^{-1}$ where highest maize equivalent yield $19.68 \mathrm{t} \mathrm{ha}^{-1}$ was recorded from the treatment $\mathrm{T}_{3}(100 \%$ maize + spinach). The same combinations also gave highest gross return (Tk. $373930 \mathrm{ha}^{-1}$ ) and gross margin (Tk. $258585 \mathrm{ha}^{-1}$ ) as well as benefit cost ratio (3.24). Though highest grain yield was recorded from sole maize but equivalent yield and economic return was much lower than the treatment $\mathrm{T}_{3}$.
\end{abstract}

\section{Introduction}

The area under charland is estimated to be about 0.83 million ha in Bangladesh. In Tangail district the total charland area is 16,736 ha (DAE, 2014). The soil of charland is structure less with poor fertility. Farmers used mostly local varieties of crops including boro rice under low management condition. Intercropping increases total productivity through efficient utilization of land, labour and growth resources (Ahmed et al., 2006). Greater productivity in intercropping system is commonly achieved by minimizing interspecific competition and maximizing complementary use of growth resources (Islam, 2002). Inter-specific competition may be minimized through judicious choice of crops (Santalla et al., 2001). Usually plants differing in growth duration, height, rooting systems and nutrient requirements are considered to grow together in intercropping systems (Reddy and Willey, 1981).

At present maize is a very popular and multi uses cereal crop. Besides, the climate of Bangladesh is suitable for maize cultivation. The rate of seed germination and seedling growth of maize are very slow in winter season due to prevailing low temperature. Farmers grow maize as a sole crop at the charland area of Bhuapur, Tangail. In that area fodder for livestock and poultry feed is acute problem. Every year a huge amount of maize grain is required as feed and fodder for poultry and livestock sector and most of them imported. 
Rahaman et al.

Maize is a long duration crop which takes about five months so, short duration vegetable crops like red amaranth, radish, spinach, potato could be grown in between maize rows at early stages to get quick return. Vegetable are the main component of human food that supplies proteins, carbohydrates, fats, vitamins and minerals. At present vegetable production is much less than the requirement. However, there is a limited scope for bringing additional land for vegetable cultivation. So, alternate option is to grow vegetables per unit area through intercropping system. Hence, this experiment was designed to study the feasibility and agro-economic performance of maize intercropping with different short duration vegetable crops.

\section{Materials and Methods}

The experiment was conducted at MLT site Bhuapur, Tangail during rabi season of two consecutive years of 2012-13 and 2013-14 under AEZ\#8. The experiment was laid out in a Randomized Complete Block Design with six dispersed (six farmers' field) replications. Five treatment combinations viz. $\mathrm{T}_{1}=$ Sole Maize, $\mathrm{T}_{2}=100 \%$ Maize (maize paired row) + Potato (var. Diamant), $T_{3}=100 \%$ Maize (maize paired row) + Spinach (var. local), $T_{4}=100 \%$ Maize (maize paired row) + Red amaranth (var. BARI Lalshak-1) and $\mathrm{T}_{5}=100 \%$ Maize (Maize paired row) + Radish (var. BARI Mula-1) were studied. The unit plot size was $8 \mathrm{~m} \times 5 \mathrm{~m}$. Three rows $(45 \mathrm{~cm} \times 20 \mathrm{~cm})$ of potato, spinach (broadcast), red amaranth (broadcast) and four rows $(30 \mathrm{~cm} \times 10 \mathrm{~cm})$ of radish were sown in between paired rows of maize (maize paired row spacing was $150 \mathrm{~cm}$, line to line spacing $37.5 \mathrm{~cm}$ and plant to plant $25 \mathrm{~cm}$ ). The spacing for sole and intercropping maize was $75 \mathrm{~cm} \times 25 \mathrm{~cm}$. Maize, potato, spinach, red amaranth and radish seeds were sown during 20-27 November, 2012 and 25-30 November, 2013. Fertilizers were applied @ 255-55-140-40-6-2 kg ha-1 N-P-K-S-Zn-B for maize. 1/3 N and full amount of other fertilizers were applied as basal. Rest $\mathrm{N}$ was applied in maize rows as top dress in two equal splits at 30 and 60 days after sowing (DAS). Subsequently three irrigations were applied at 20,30 and 60 DAS. Earthling up was done at 30 days after planting potato. Two hand weeding were done at 20 and 35 DAS to keep the crop weed free. The main crop (maize) was harvested from 23 April to 2 May, 2013 and 15-20 April, 2014. The intercropped vegetables such as potato, spinach, red amaranth and radish were harvested at 90-94, 31-42, 27-41 and 50-66 DAS, respectively in both cropping season. Yield component data of crops were collected prior to harvest from each plot. Data of two years were analyzed statistically and mean comparison was done by LSD test. The relative yield was obtained by dividing the intercrop yield of a crop with the respective sole crop yield of that crop using the formula (Dewit and Vander Bergh, 1965).

The relative yield of a crop $=\frac{\text { Yield of component crops }}{\text { Yield of sole crop }}$

Maize equivalent yield was calculated by converting the yield of red amaranth, radish, spinach, potatointo the yield of maize on the basis of prevailing market price using the formula of Anjaneyulu et al. (1982). Benefit cost analysis were also done.

Maize equivalent yield (for vegetables) $=\mathbf{Y m}+\frac{\text { Yint } \mathbf{x} \text { Pint }}{\mathbf{P m}}$

$Y m=$ Yield of maize, $\mathrm{Pm}=$ sales price of maize, Yint = yield of intercrop (potato, spinach, red amaranth and radish).

\section{Results and Discussion}


On-Farm Study On Intercropping Of Hybrid Maize

\section{Effect on yield and yield components of maize}

Yield and yield contributing characters of intercropped maize were statistically significant (Table 1). The highest plant height $189.60 \mathrm{~cm}$ was recorded from sole maize and the lowest plant height 148.27 was obtained from maize + radish intercropping combination. The highest number of grains $\mathrm{cob}^{-1} 502.93$ was recorded from sole maize plot and the lowest number of grains $\mathrm{cob}^{-1} 371.60$ was found in maize + radish intercropping combination. The same trend was observed in case of 1000- grain weight and it was ranged from 291.70$324.60 \mathrm{~g}$ in different treatments. The highest 1000 - grain weight $324.60 \mathrm{~g}$ was recorded from sole maize and the lowest 1000 - grain weight 291.70 was obtained from maize + radish intercropping combination. The highest grain yield $\left(8.17 \mathrm{t} \mathrm{ha}^{-1}\right)$ was recorded from sole maize, which could be due to higher no. of grains $\mathrm{cob}^{-1}$ and 1000 grain weight. The grain yield of maize in intercropped combination varied from 5.59-7.62 $\mathrm{t} \mathrm{ha}^{-1}$. The yield data indicated that due crop competition in intercropping yield loss of maize was observed.

\section{Effect of intercrops}

The intercrop yield of potato, spinach, red amaranth and radish were influenced significantly by different intercropping combinations (Table 2). The highest vegetable yield was recorded from radish in maize + radish intercropping combination $\left(22.03 \mathrm{t} \mathrm{ha}^{-1}\right)$ followed by spinach combination $\left(19.65 \mathrm{t} \mathrm{ha}^{-1}\right)$. The lowest yield was obtained from red amaranth in maize + red amaranth intercropping combination $\left(7.40 \mathrm{t} \mathrm{ha}^{-1}\right)$.

\section{Relative yield}

Relative yield determines competitive ability of component crops in intercropping system. Greater value of relative yield showed more competitive ability in intercrop situation compared to its monoculture (Juskiw et al., 2000). The relative yields of maize were 0.93 , 0.89 , and 0.89 and 0.68 when maize was intercropped with potato, spinach, red amaranth and radish, respectively (Table 2 ). This indicates that maize yield was reduced by $6.73 \%$, $11.02 \%, 11.38 \%$ and $31.58 \%$ as compared to sole crop when it was intercropped with potato, spinach, red amaranth and radish, respectively. It indicates that potato yield was adversely affected and less by growing radish. The lower relative yield of maize in intercropping indicated that the crop faced competition for space, nutrients, light, and water. The findings are in agreement with that of Hossain et al. (2015).

\section{Maize equivalent yield}

All the intercropped combinations showed higher maize equivalent yield than sole maize in all cases. Among the treatments, the highest maize equivalent yield $\left(19.68 \mathrm{t} \mathrm{ha}^{-1}\right)$ was obtained from maize + spinach intercrop combination (Table 2). The lowest maize equivalent yield $\left(11.39 \mathrm{t} \mathrm{ha}^{-1}\right)$ was obtained from maize + radish intercrop combination. Although maize yield was $6.73,11.02,11.38$ and $31.58 \%$ lower than sole crop when it was intercropped with potato, spinach, red amaranth and radish. But maize equivalent yield from maize + potato, maize + spinach, maize + red amaranth and maize + radish intercrop combination showed $77.92,140.89,45.72$ and $39.36 \%$ higher yield advantage over the sole maize respectively. This result showed that maize + spinach was the best intercrop combination in respect of total yield advantage.

\section{Cost return analysis}

An analysis on cost and return of intercropping maize with different short duration vegetables has been presented in Table 3. Higher gross return was obtained from all intercrop combinations than sole crop. Among the combinations, the highest gross return (Tk. 37390. 
Rahaman et al.

ha- ${ }^{1}$ ) was obtained from maize + spinach intercropping system, which was $140.89 \%$ higher than sole maize (Tk. 155230. ha- ${ }^{1}$ ). Among the intercrop combinations the lowest gross return (Tk. 216335 ha- $^{1}$ ) was found form maize + radish intercrop. Almost similar trend was followed in case of gross margin. The highest benefit-cost ratio (3.24) was recorded from maize + spinach combination due to yield and economic advantage but maize + potato can be grown through potato yield reduced substantially.

Table 1. Yield and yield contributing characters of maize and yield of vegetables under intercropping situation in charland Bhuapur, Tangail

\begin{tabular}{|c|c|c|c|c|c|c|c|c|c|}
\hline \multirow[t]{2}{*}{$\begin{array}{l}\text { Treatmen } \\
\mathrm{t}\end{array}$} & \multirow{2}{*}{$\begin{array}{c}\text { Plant } \\
\text { height } \\
(\mathrm{cm})\end{array}$} & \multirow{2}{*}{$\begin{array}{l}\text { Grains } \\
\mathrm{cob}^{-1} \\
\text { (no.) }\end{array}$} & \multirow{2}{*}{$\begin{array}{l}1000- \\
\text { grain } \\
\text { wt. (g) }\end{array}$} & \multicolumn{3}{|c|}{ Maize grain yield $\left(\mathrm{t} \mathrm{ha}^{-1}\right)$} & \multicolumn{3}{|c|}{$\begin{array}{c}\text { Vegetable yield } \\
\left(\mathrm{t} \mathrm{ha}^{-1}\right)\end{array}$} \\
\hline & & & & 2012-13 & 2013-14 & Mean & $2012-13$ & 2013-14 & Mean \\
\hline $\mathrm{T}_{1}$ & 189.60 & 502.93 & 324.60 & 8.11 & 8.23 & 8.17 & - & - & - \\
\hline $\mathrm{T}_{2}$ & 183.93 & 484.45 & 319.07 & 7.51 & 7.73 & 7.62 & 13.48 & 12.80 & 13.14 \\
\hline $\mathrm{T}_{3}$ & 171.65 & 483.83 & 312.62 & 6.97 & 7.57 & 7.27 & 21.02 & 18.28 & 19.65 \\
\hline $\mathrm{T}_{4}$ & 173.47 & 478.02 & 311.73 & 7.24 & 7.23 & 7.24 & 7.92 & 6.87 & 7.40 \\
\hline $\mathrm{T}_{5}$ & 148.27 & 371.60 & 291.70 & 5.11 & 6.07 & 5.59 & 21.32 & 22.73 & 22.03 \\
\hline $\operatorname{LSD}_{(0.05)}$ & 11.27 & 17.49 & 4.65 & 0.18 & 0.35 & - & 0.45 & 1.17 & - \\
\hline CV (\%) & 5.40 & 3.10 & 1.20 & 2.08 & 3.90 & - & 2.93 & 8.00 & - \\
\hline
\end{tabular}

$\mathrm{T}_{1}=$ Sole crop of Maize (100\% Maize)

$\mathrm{T}_{2}=100 \%$ Maize (Maize paired row) + Potato (Diamant)

$\mathrm{T}_{3}=100 \%$ Maize (Maize paired row) + Spinach

$\mathrm{T}_{4}=100 \%$ Maize (Maize paired row) + Red amaranth (BARI Lalshak-1)

$\mathrm{T}_{5}=100 \%$ Maize (Maize paired row) + Radish (BARI Mula-1)

Table 2. Maize grain yield, vegetable yield, maize relative and equivalent yield influenced by intercropping with vegetables at Bhuapur, Tangail

\begin{tabular}{c|c|c|c|c}
\hline Treatment & $\begin{array}{c}\text { Maize grain yield } \\
\left(\mathrm{t} \mathrm{ha}^{-1}\right)\end{array}$ & $\begin{array}{c}\text { Vegetable yield } \\
\left(\mathrm{t} \mathrm{ha}^{-1}\right)\end{array}$ & $\begin{array}{c}\text { Relative yield of } \\
\text { maize }\end{array}$ & $\begin{array}{c}\text { Maize equivalent } \\
\text { yield } \\
(\mathrm{t} \mathrm{ha})\end{array}$ \\
\hline $\mathrm{T}_{1}$ & 8.17 & - & - & 8.17 \\
$\mathrm{~T}_{2}$ & 7.62 & 13.14 & 0.93 & 14.54 \\
$\mathrm{~T}_{3}$ & 7.27 & 19.65 & 0.89 & 19.68 \\
$\mathrm{~T}_{4}$ & 7.24 & 7.40 & 0.89 & 11.91 \\
$\mathrm{~T}_{5}$ & 5.59 & 22.03 & 0.68 & 11.39 \\
\hline
\end{tabular}

Table 3. Cost and return analysis of maize intercropping with vegetables at Bhuapur, Tangail

\begin{tabular}{c|c|c|c|c}
\hline Treatment & $\begin{array}{c}\text { Gross return } \\
\left(\text { Tk. ha }^{-1}\right)\end{array}$ & $\begin{array}{c}\text { Cost of production } \\
\left(\text { Tk. ha }^{-1}\right)\end{array}$ & $\begin{array}{c}\text { Gross margin } \\
\left(\text { Tk. ha }^{-1}\right)\end{array}$ & $\begin{array}{c}\text { Benefit-Cost Ratio } \\
\text { (BCR) }\end{array}$ \\
\hline $\mathrm{T}_{1}$ & 155230 & 84350 & 70880 & 1.84 \\
$\mathrm{~T}_{2}$ & 276180 & 121650 & 154530 & 2.27 \\
$\mathrm{~T}_{3}$ & 373930 & 115345 & 258585 & 3.24 \\
$\mathrm{~T}_{4}$ & 226205 & 112170 & 114035 & 2.02 \\
$\mathrm{~T}_{5}$ & 216335 & 109575 & 106760 & 1.97 \\
\hline
\end{tabular}

Price $\left(T k . \mathrm{kg}^{-1}\right)$ : Maize $=19 /-$, Potato $=10 /-$, Spinach $=12 /-$, Red amaranth $=12 /-$ and Radish $=5 /-$

Farmers' opinion: Maize with short duration intercrops (potato, spinach, red amaranth and radish) was observed as a profitable practice in char land area. As such they can earn extra income easily without hampering the main crop (maize) yield and can help to meet up the vegetable requirement of the family of char land area where acute problems of vegetables. 
On-Farm Study On Intercropping Of Hybrid Maize

\section{Conclusion}

From the results, it revealed that maize grown as intercrop with short duration vegetables like potato, spinach, red amaranth and radish may be profitable than sole maize. All of the intercrop combinations are agronomically and economically viable than sole cropping. But, he results suggested that the possibility of obtaining a reasonably good yield and profitable economic return from intercropping maize with spinach in char land area of Bhuapur, Tangail.

\section{References}

Ahmed, F., M. A. Rahman, M. A. H. S. Jahan, M. Ahmed and M. A. Khayer. 2006. Effect of different planting systems in maize/spinach-red amaranth intercropping. Bangaldesh $\mathrm{J}$. Agric. and Environ. 2(2): 69-76.

Anjaneyulu, V. R., S. P. Singh and M. Pal. 1982. Effect of competition free period and technique and pattern of pearmillet planting on growth and yield of mungbean and total productivity in solid pearlmillet and pearlmillet and pearlmillet/mungbean intercropping system. Indian J. Agron.27(3):219-226).

DAE. 2014. Area and production of major crops and major cropping pattern of Tangail District. Department of Agricultural Extension (DAE), Tangail, Bangladesh. May 2014.

Dewit, C. T. and J. P. Vander Bergh. 1965. Competition between herbage plants. Neth. J. Agric. Sci. 13: 212-221.

Hossain, M. H., S. K. Bhowal and A. S. M. M. R. Khan. 2015. Intercropping system of maize with different winter vegetables. Malays. J. med. boil. res. 2: 153-156.

Isalm, M. N. 2002. Competitive interference and productivity in maize-bushbean intercropping system. A PhD. Dissertation, Dept. of Agronomy, Bangabandhu Sheikh Mujibur Rahman Agricultural University, Gazipur.

Juskiw, P. E., J. H. Helim and D. F. Salman. 2000. Competitive ability in mixtures of small grain cereals. Crop Sci. 40: 159-164.

Reddy, M. S and R. W. Willey. 1981. Growth and resource use studies in an intercrop of pearl millet/groundnut. Field crops res. 4: 13-24.

Santalla, M., A. P. Rodino, P. A. Casquero and A. M. De Ron. 2001. Interactions of bushbean intercropped with field and sweet maize. European J. Agron. 15: 185-196. 